\title{
Prostat kanserinin tanısında gri skala ve renkli Doppler ultrasonografinin yeri
}

\author{
Gray scale and color Doppler ultrasonography findings in the diagnosis of prostate \\ cancer
}

\author{
Ergin Sağtaş, Mahmut Refik Killi
}

Gönderilme tarihi:16.07.2018

Kabul tarihi:09.11.2018

\section{Özet}

Amaç: Bu çalışmanın amacı prostat kanserinde transrektal gri skala ultrasonografi (US) bulguları ile tümörlerin malignite potansiyelleri arasındaki ilişkiyi incelemek ve transrektal renkli Doppler ultrasonografinin (RDUS) tanıya olan katkısını araştırmaktır.

Gereç ve yöntem: Çalışmamızda TRUS eşliğinde yapılan biyopsi sonrası prostat kanseri saptanan 63 olgu değerlendirilmiştir. Hastaların tümünde gri skala US, RDUS bulguları, serum PSA düzeyleri, patoloji sonuçları karşılaştırımış ve aralarındaki ilişki araştırı Imıştır.

Bulgular: Orta diferansiye tümörler daha çok hipoekojenik iken (\%69), kötü diferansiye tümörlerin mikst ekojenitede oldukları gözlenmiştir (\%58). İzoekojenik tümörlerin tümü iyi ya da orta derece diferansiye grupta yer almışlardır. Toplam 65 kanser odağının 11'inde (\%17) Doppler bakıda kanlanma saptanmazken (derece 0), 8'inde (\%12) 1. derece ve 46'sında (\%71) 2. derece kanlanma izlenmiştir. Lezyonların kanlanma derecesi artııça PSA değerlerinin belirgin olarak arttığı belirlenmiştir. Tümörlerin Gleason skorları ile kanlanma dereceleri arasında da önemli bağlantılar tespit edilmiştir. RDUS ile kanlanma saptanmayan lezyonların tamamı iyi ya da orta derece diferansiye kanser grubundadır. Buna karşın belirgin kanlanma saptanan kanserlerin büyük çoğunluğu (\%98) orta ya da kötü diferansiye grupta yer almaktadır.

Sonuç: Prostat kanseri saptanmasında RDUS'nin gri skala US'ye ilave katkısı bulunmamıştır. Ancak gri skala US ile kuşkulu lezyonların manifest hale gelmesine katkıda bulunduğu gözlenmiştir. Kanserlerin kanlanma dereceleri ile Gleason skorları arasında önemli bağlantılar dikkati çekmiştir. Buna göre RDUS ile belirgin kanlanma gösteren kanserlerin, kanlanmayan ya da minimal kanlanma izlenen kanserlere göre daha yüksek maligniteye sahip oldukları gözlenmiştir.

Anahtar Kelimeler: Prostat kanseri, transrektal ultrasonografi, renkli Doppler ultrasonografi, Gleason skoru.

Sağtaş E, Killi MR. Prostat kanserinin tanısında gri skala ve renkli Doppler ultrasonografinin yeri. Pam Tıp Derg 2019;12:67-76.

\begin{abstract}
Purpose: The aim of this study is to investigate the relationship between tumoral malignancy potentials and transrectal gray scale ultrasonographic findings in prostate cancer and to investigate the contribution of transrectal color Doppler ultrasonography to the diagnosis.

Material and methods: We evaluated 63 patients with prostate cancer who underwent transrectal associated biopsy in our study. In all patients, gray scale ultrasonography, color Doppler ultrasonography findings, serum PSA levels, pathology results were compared and the relationship between them was investigated.

Results: While moderately differentiated tumors were more hypoecogenic (69\%), poorly differentiated tumors were observed to have mixed echogenicity $(58 \%)$. All of the isoecogenic tumors were in the good or moderate differentiation group. In 11 (17\%) of 65 cancer regions, no blood flow was detected in Doppler US (grade 0). Eight $(12 \%)$ of 65 patients had first degree blood flow, while $46(71 \%)$ had second degree blood flow. It was determined that the PSA values significantly increased as the degree of vascularization of the lesions increased. Significant correlations were also found between the Gleason scores of the tumors and the blood flow grade. All lesions with no evidence of color Doppler ultrasonography are found in the good or moderately differentiated cancer group. On the other hand, the majority $(98 \%)$ of the cancers in which significant blood flow is detected are found in the moderate or poorly differentiated group.

Conclusion: There was no additional contribution of color Doppler ultrasonography to gray scale ultrasonography in detecting prostate cancer. However, it has been observed that the gray scale ultrasonography contributes to the manifestation of suspicious lesions. Significant links between cancer blood levels and Gleason scores were noted. Accordingly, it has been observed that cancers that show significant blood flow with color Doppler ultrasonography have higher malignancy than cancers that do not have blood or minimal blood supply.
\end{abstract}

Ergin Sağtaş, Dr.Öğr.Üyesi, Pamukkale Üniversitesi Tıp Fakültesi, Radyoloji Anabilim Dalı, DENiZLi, e-posta:sagtasergin@yahoo.com (orcid. org/0000-0001-6723-6593) (Sorumlu yazar)

Mahmut Refik Killi, Prof.Dr. İstanbul Florence Nightingale Hastanesi, Radyoloji Bölümü, isTANBUL, e-posta:refik.killi@florence.com.tr (orcid. org/0000-0002-9307-242X) 
Key words: Prostate cancer, transrectal ultrasonography, color Doppler ultrasonography, Gleason score.

Sağtaş E, Killi MR. Gray scale and color Doppler ultrasonography findings in the diagnosis of prostate cancer. Pam Med J 2019;12:67-76.

\section{Giriş}

Prostat kanseri erkek kanserleri arasında ilk sırada, kansere bağlı ölümlerde ise akciğer kanserinden sonra ikinci sırada yer almaktadır. Prostat kanseri yaşlılık dönemi hastalığıdır ve 50 yaş altında nadiren görülür. Bu yaştan itibaren görülme sıklığı hızla artar ve 8'inci dekadda en yüksek seviyeye ulaşır [1].

Prostat kanserinin evresi, derecesi, hastanın yaşı, medikal bir başka hastalık veya malignite bulunması hastalığın seyrini etkiler. Genellikle düşük evreli ve düşük dereceli kanserler tedavi yapılsın veya yapılmasın iyi prognoza sahiptir. Diğer taraftan yüksek evreli ve yüksek dereceli kanserler tedaviye bakılmaksızın kötü prognozludur. Orta dereceli kanserlerde ise uygun tedavi prognozu genellikle olumlu yönde etkilemektedir [2].

Prostat kanseri taramasında parmakla rektal muayene, serum prostat spesifik antijen (PSA) düzeyi ve transrektal ultrasonografi (TRUS) "diagnostik triad" olarak kabul edilmektedir. Önceki araştırmalar bu üçlünün kombine edilmesiyle tanı değerinin arttığını göstermiştir. Ancak diğer organ tümörlerinde olduğu gibi tanı biyopsi ile histopatolojik olarak kesinleştirilmelidir [3]

TRUS günümüzde ucuz, pratik ve iyi tolere edilebilir olması nedeniyle en sık kullanılan tanı yöntemidir. TRUS ile prostatın iç yapısı iyi bir şekilde değerlendirilebilmekte ve aynı zamanda büyüklüğü de doğru olarak ölçülebilmektedir. Ancak TRUS birçok prostat patolojisinin histolojik tanısı için spesifik değildir. Çoğu kez sonografik bulgulara bakarak kanser ve benign patolojiler arasında ayırım yapmak mümkün değildir. Histopatolojik tanı biyopsiye bağımlıdır. Günümüzde çoğu prostat biyopsileri TRUS rehberliğinde yapılmaktadır. Küçük çaplı iğneler ve yaylı biyopsi tabancası gibi modern biyopsi cihazlarının kullanımı ile bu yöntem iyi tolere edilmekte ve hastalar için düşük risk taşımaktadır [4].
Literatürde transrektal renkli Doppler ultrasonografinin (RDUS) prostat kanseri tanısında transrektal gri skala ultrasonografiye (US) ilave katkısını araştırmak amacıyla farklı çalışmalar vardır [5-8].

$\mathrm{Bu}$ çalışmanın amacı prostat kanserinde transrektal gri skala US bulguları ile tümörlerin malignite potansiyelleri arasındaki ilişkiyi incelemek ve transrektal RDUS'nin tanıya olan katkısını araştırmaktır.

\section{Gereç ve yöntem}

$\mathrm{Bu}$ çalışmada yerel etik kurul onayını takiben, parmakla rektal muayene sonrası kanser yönünden kuşku duyulan ya da PSA değerleri $4 \mathrm{ng} / \mathrm{ml}$ üzerinde saptanan hastalar gri skala US ve Doppler US ile değerlendirilmiştir. $\mathrm{Bu}$ hastalardan, transrektal ultrasonografi eşliğinde yapılan biyopsi sonucunda, prostat kanseri saptanan toplam 63 olgu çalışma kapsamına alınmıştır. Hastaların tümü çalışma ile ilgili bilgilendirilmiş ve aydınlatılmış onamları alınmıştır.

Çalışmamızda Toshiba firmasına ait SSA 270A Renkli Doppler US cihazı ile 6 ve 7 $\mathrm{MHz}$ frekanslarında çalışan PVL-725 RT biplan (lineer-konveks) endorektal transduser kullanılmıştır. Biyopsi işleminde ise biyopsi tabancası ve özel olarak dizayn edilmiş 16 ve 18 gauge Tru-cut biyopsi iğneleri kullanılmıştır. Gri skala US seminal veziküller düzeyinden apekse kadar aksiyel ve bezin sağ kenarından sol kenarına kadar sagittal planlarda yapılmıştır.

Hastaların tamamında prostat hacmi elde olunmuş ve PSA dansitesi (PSAD) değerleri hesaplanmıştır. Prostat hacmi organın elipsoid olduğu kabul edilerek ön-arka çapxtransvers çapxsagittal çapx1/2 formülüne göre hesaplanmıştır [9]. PSAD ise, PSA değerinin TRUS ile saptanan prostat hacmine bölünmesi ile elde olunmuştur.

Gri skala inceleme sonrası RDUS ile değerlendirme yapılmıştır. Öncelikle lezyonun 
en iyi şekilde saptanabilmesi amacıyla uygun Doppler parametreleri belirlenmiştir. Buna göre; periferik bölgede belirgin Doppler paraziti izlenmeyecek, ancak çevredeki normal vaskülarite (ör. nörovasküler demet) görülebilecek şekilde ayarlamalar yapılmıştır. Uygun olmayan Doppler parametreleri normal vaskülariteyi abartabilmekte ve tümör neovaskülaritesinin gözden kaçmasına da neden olabilmektedir [5, 7]. Daha sonra tüm kadranlar, özellikle periferik bölge anormal kanlanma yönünden detaylı olarak incelenmiştir. Gri skala US'de periferik bölgede saptanan hipo ya da mikst ekojenitedeki lezyonlar patolojik kanlanma yönünden RDUS ile tekrar değerlendirilmiştir.

RDUS'de patolojik kanlanma saptanan prostat alanlarının değerlendirilmesinde; akımın varlığına ve miktarına göre 0 ile 2 arasındaki değerlere sahip özel bir sistem kullanılmıştır;

Derece 0: Periferik zonda artmış kan akımı yok (Resim 1),

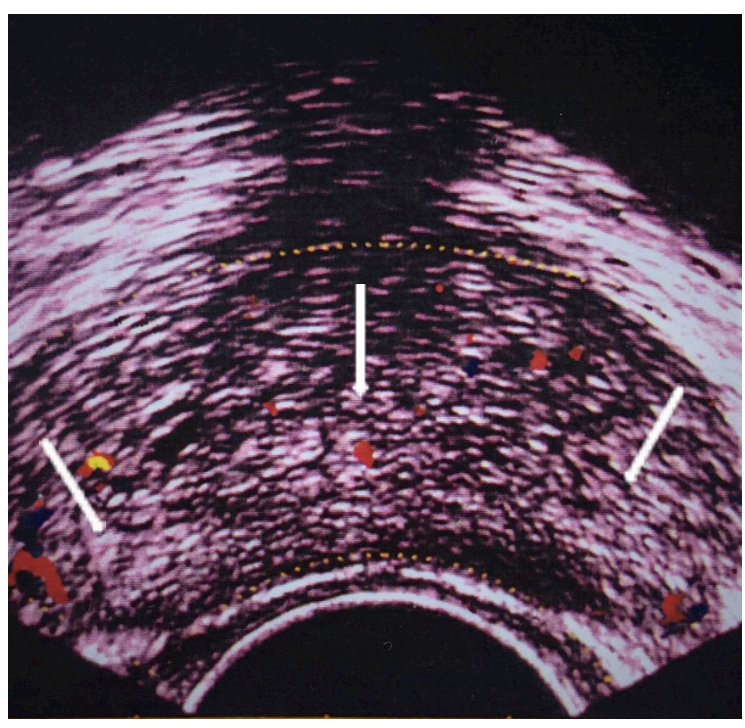

Resim 1. Prostat periferik bölgede patolojik kanlanma izlenmemektedir (derece 0) (oklar).
Derece 1: Periferik zonda minimal artmış kan akımı (Resim 2),

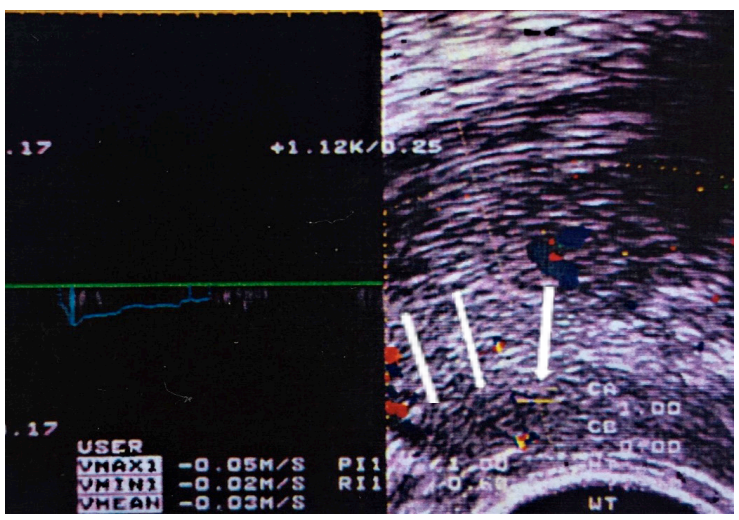

Resim 2. Prostat sağ periferik bölgede minimal kanlanma (derece 1) gösteren hipoekojenik tümör izlenmektedir (oklar)

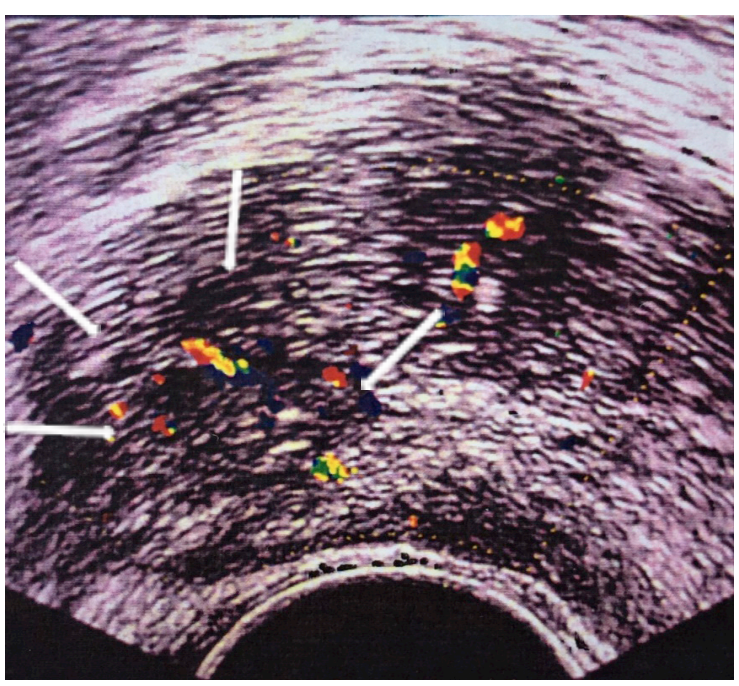

Resim 3. Prostat sağ periferik bölgede belirgin kanlanma (derece 2) gösteren hipoekojenik tümör mevcuttur (oklar)

Derece 2: Periferik zonda belirgin derecede artmış kan akımı (Resim 3).RDUS sonrasında ise lezyon içinde yer alan arteriyel vasküler yapılardan spektral Doppler inceleme yapılmış ve ortalama rezistif indeks (RI) (Rİ=Maksimum sistolik hız-Diastol sonu hı/Maksimum sistolik hız) ile ortalama pulsatilite indeksi (PI) (PI=Maksimum sistolik hız-Diastol sonu hız/ortalama hız) değerleri elde olunmuştur. $\mathrm{Bu}$ değerlerin belirlenmesinde, tetkiklerde kullanılan ultrasonografi cihazı içinde yer alan otomatik ölçüm programları kullanılmıştır. 
Gri skala ve RDUS incelemeler sonrasında biyopsi işlemine geçilmiştir. Ultrasonografik incelemede fokal lezyon saptanmayan olgularda rutin olarak 8 kadran sistematik biyopsi yapılmıştır. Bu amaçla prostat bezinin taban, orta, apeks ve transisyonel zon bölgelerinden bilateral biyopsiler alınmıştır. Gri skala ve RDUS ile periferik zonda fokal lezyon saptanan tüm olgularda ise lezyona yönelik iki ya da üç biyopsi yapılmıştır. Daha sonra ilave olarak geri kalan kadranlardan da biyopsiler elde olunmuştur.

Elde olunan biyopsi materyalleri, biyopsinin alındığı kadranı göstermek üzere, ayrı formalin şişelerine konulmuş ve patoloji bölümüne gönderilmiştir. Materyallerin tümü Gleason skoruna göre derecelendirilmiştir. Gleason skorlarına göre, tümörler 3 kategoride gruplandırılmıştır. Buna göre; iyi diferansiye tümörler (Gleason derece 2-4) birinci kategoride, orta diferansiye tümörler (Gleason derece 5-7) ikinci kategoride ve anaplastik tümörler (Gleason derece 8-10) üçüncü kategoride ele alınmıştır.

Biyopsi işlemi sırasında ve sonrasında, prostat bezi ve çevre dokularda ortaya çıkabilecek olası komplikasyonların belirlenebilmesi için gri-skala TRUS ve RDUS ile ilave değerlendirmeler yapılmıştır.

\section{Bulgular}

Transrektal ultrasonografi eşliğinde 63 hastaya yapılan 8 kadran biyopsi sonrası toplam 65 prostat kanseri odağı saptanmıştır. Gri skala US ve RDUS'de kanser saptanan 57 hastada lezyona yönelik ilave biyopsiler alınmıştır. PSA değerleri normalin üstünde ancak gri skala US ve RDUS ile lezyon saptanmayan 6 hastada ise 8 kadran sistematik biyopsi yapılmıştır.

Çalışma grubunda yer alan hastaların yaşları 50 ile 88 arasında (ortalama 67,5) değişmektedir. Hastaların en çok 60-79 yaşları arasında bulundukları belirlenmiştir (50/63 hasta). En az hasta sayısının ise 80 yaş ve üzeri grupta yer aldığı dikkati çekmiştir (3/63 hasta).

PSA değerleri sadece bir hasta $(\% 1,5)$ dışında tüm olgularda normal sınır kabul edilen $4 \mathrm{ng} / \mathrm{ml}$ 'nin üzerinde bulunmuştur. Bu tek olguda parmakla rektal muayenenin kuşkulu bulunması üzerine TRUS yapılmış ve kanser saptanmıştır. En düşük PSA değeri $3 \mathrm{ng} / \mathrm{ml}$, en yüksek PSA değeri ise $200 \mathrm{ng} / \mathrm{ml}$ (ortalama 36 $\mathrm{ng} / \mathrm{ml}$ ) olarak bulunmuştur. Prostat hacimleri kullanılarak hastaların tümünde PSAD değerleri hesaplanmış ve 0,06 ile 5,77 (ortalama 1,00) arasında bulunmuştur. Dört hastada ise $(\% 6,3)$ PSAD değerleri prostat kanseri için sınır kabul edilen 0,15 'in altında tespit edilmiştir.

Biri dışında tüm hastalarda biyopsi materyalleri Gleason skorlaması için yeterli histolojik düzeyde bulunmuştur. Gleason skorları 3 grup altında incelenmiştir. En çok olgu Gleason 5-7 skorlarında bulunmuştur (\%52). Gleason skorları genel ortalaması 6,5 olarak hesaplanmıştır. Gleason skorlarına göre hasta sayısı ve bunların PSA ortalamaları ile ilişkileri Tablo 1'de incelenmiştir. Tabloda görüldüğü gibi Gleason skorlarına paralel olarak ortalama PSA değerleri de artmaktadır.

Tablo 1. Olguların Gleason skorlarına ve ortalama PSA değerlerine göre dağılımı. PSA, prostat spesifik antijen.

\begin{tabular}{ccc}
\hline $\begin{array}{c}\text { Gleason } \\
\text { Skorları }\end{array}$ & $\begin{array}{c}\text { Hasta Sayısı } \\
(\%)\end{array}$ & Ortalama PSA \\
\hline $2,3,4$ & $8(\% 13)$ & 13,9 \\
$5,6,7$ & $32(\% 52)$ & 23,8 \\
$8,9,10$ & $22(\% 35)$ & 63 \\
Toplam & $62(\% 100)$ & \\
\hline
\end{tabular}

\section{Gri skala US bulguları}

Prostat bezinin periferik bölgesinde hipoekojenik kanser odağı 32 hastada (\%49), mikst ekojenitede kanser ise 25 hastada (\%39) tespit edilmiştir. Hiçbir hastada izole hiperekojenik kanser saptanmamıştır. Mikst ekojenitede kanser saptanan 2 hastada gri skala US ve RDUS ile bakıda bezin bir yarısında lezyon gözlenirken, diğer yarısı normal bulunmuştur. Ancak patoloji sonuçlarına göre, bu iki hastada lezyon saptanmayan diğer prostat bölgelerinde de tümör bulunmuştur. Buna bağlı olarak bu odaklar gri skala US'de izoekojenik kanser, RDUS'de ise kanlanma saptanmayan tümör grubuna dahil edilmiştir. $\mathrm{Bu}$ durum gözönüne alındığında 63 hastada 65 odak değerlendirmeye alınmıştır. Aynı anda iki farklı özellikte kanser odağı saptanan bu iki hastanın bir tanesinde Gleason skorlaması için yeterli materyal alınamamıştır.

Altı hastada gri skala US bakıda periferik bölgede kanser saptanmamıştır. Bu grup izoekojenik kanserleri oluşturmaktadır. Yukarıda 
bahsedilen 2 izoekojenik lezyon bu gruba dahil edildiğinde toplam 8 hastada (\%12) izoekojenik kanser odağı tespit edilmiş olmaktadır.

Kanserlerin ekojenik özellikleri ile Gleason skorları arasındaki bağlantı araştırıımıştır (Tablo 2). Ancak bir hastada Gleason skorlaması yapılamadığı için incelemeye dahil edilmemiştir. Bu hastada mikst ekojenik ve izoekojenik toplam iki lezyon birlikte görüldüğü için değerlendirmeye dahil edilen kanser odağı sayısı 63 olmuştur. Genel olarak tümörlerin eko özelliklerinin Gleason skorlarına yansıdığı gözlenmiştir. Orta diferansiye tümörler daha çok hipoekojenik iken (\%69), kötü diferansiye tümörlerin mikst ekojenitede oldukları gözlenmiştir (\%58).
İzoekojenik tümörlerin tümü iyi ya da orta derece diferansiye grupta yer almışlardır. Mikst ekojenitedeki tümörlerin ise daha çok kötü diferansiye grupta yer aldıkları dikkati çekmiştir. İyi diferansiye grupta ise sadece bir hastada mikst ekojenitede kanser odağı saptanmıştır.

Lezyonların ekojenik özelliklerine göre ortalama PSA değerleri Tablo 3'te izlenmektedir. Aynı anda izoekojenik ve mikst ekojenik kanser içeren 2 hasta değerlendirmeye dahil edilmemiştir. İzoekojenik kanserlerin diğerlerine göre daha düşük PSA değerlerine sahip olduğu belirlenmiştir. Buna karşın mikst ekojenitedeki tümörler en malign potansiyele sahip grubu teşkil etmektedirler ve ortalama PSA değerleri

Tablo 2. Kanserlerin ekojenik özelliklerine ve Gleason skorlarına göre dağılımı.

\begin{tabular}{lcccc}
\hline & \multicolumn{3}{c}{ Gleason Skorları } \\
\hline Eko özellikleri & $2-4$ & $5-7$ & $8-10$ & Toplam \\
Hipoekojenik $(\mathrm{n}=32)$ & 3 & 22 & 7 & 32 \\
İoekojenik $(\mathrm{n}=7)$ & 4 & 3 & 0 & 7 \\
Mikst ekojenik $(\mathrm{n}=24)$ & 1 & 9 & 14 & 24 \\
Toplam & 8 & 34 & 21 & 63 \\
\hline
\end{tabular}

Tablo 3. Kanserlerin ekojenik özelliklerine ve ortalama PSA değerlerine göre dağılımı. PSA, prostat spesifik antijen.

\begin{tabular}{lc}
\hline Eko Özellikleri & Ortalama PSA \\
\hline Hipoekojenik & 30 \\
İzoekojenik & 12,5 \\
Mikst ekojenik & 49 \\
\hline
\end{tabular}

oldukça yüksektir. Ancak PSA değeri normal sınırlarda olan bir hastanın kötü diferansiye grupta yer aldığı da belirlenmiştir.

Radikal prostatektomi operasyonu uygulanan 7 hastada patoloji sonuçlarına göre seminal vezikül invazyonu saptanmıştır. Seminal vezikül invazyonu yapan bu kanserlerden, bir tanesi hipoekojenik, 6'sı ise mikst ekojenitede bulunmuştur. $\mathrm{Bu}$ kanserlerden tümünde 2 . derece kanlanma saptanmış, Gleason skoru ortalamaları 7,3 olarak ve PSA ortalamaları ise $82 \mathrm{ng} / \mathrm{ml}$ olarak tespit edilmiştir. Bu sonuçlardan anlaşılacağı gibi, seminal vezikül invazyonu yapan kanserler diğerlerine göre daha malign özellikler taşımaktadırlar.

\section{RDUS bulguları}

Olguların tümü RDUS ile değerlendirilmiştir. Daha önce bahsedilen 2 olguda aynı anda 2 . derece ve 0 . derece kanlanma saptanmıştır.
Buna göre toplam 65 kanser odağı değerlendirmeye alınmıştır. Odakların 11'inde (\%17) Doppler bakıda kanlanma saptanmazken (derece 0), 8'inde (\%12) 1. derece ve 46'sında (\%71) 2. derece kanlanma izlenmiştir (Tablo 4). Kanlanma derecesi arttıkça PSA değerlerinin de belirgin olarak arttığı belirlenmiştir. Aynı anda 2 tümör odağına sahip olan 2 olgu ortalama PSA hesaplamalarına dahil edilmemiştir.

Olguların 42'sinde rezistivite (Rİ) ve 34'ünde pulsatilite indeksleri (PI) hesaplanmıştır. Ortalama Rí değeri 0,77 ve ortalama $\mathrm{PI}$ değeri ise 1,34 olarak bulunmuştur. Kanlanma derecelerine göre ortalamalar hesaplandığında, ortalama Ri değeri, derece 1 'de 0,75 , derece 2 'de 0,77 ; ortalama $\mathrm{PI}$ değeri ise derece 1 'de 0,96 , derece 2'de 1,4 olarak bulunmuştur (Tablo 5). Buna göre, Pİ değerleri kanlanma dereceleri ile doğru orantılı olarak artarken; RI değerlerinde artış gözlenmemiştir. 
Tablo 4. Olguların kanlanma derecelerine ve ortalama PSA değerlerine göre dağııımı. PSA, prostat spesifik antijen.

$\begin{array}{lcc}\text { Kanlanma Derecesi } & \text { Olgu Sayısı (\%) } & \text { Ortalama PSA } \\ \text { Derece 0 } & 11(\% 17) & 12,3 \\ \text { Derece 1 } & 8(\% 12) & 24 \\ \text { Derece 2 } & 46(\% 71) & 40,6\end{array}$

Tablo 5. Kanserlerin kanlanma derecelerine göre ortalama Ri ve Pí değerlerinin dağılımı. Rí, rezistivite indeksi; $\mathrm{PI}$, pulsatilite indeksi.

\begin{tabular}{lcc}
\hline Kanlanma Derecesi & Ortalama Ri & Ortalama Pi \\
\hline Derece 0 & -- & -- \\
Derece 1 & 0,75 & 0,96 \\
Derece 2 & 0,77 & 1,4 \\
\hline
\end{tabular}

Gri skala US'de hipo ve mikst ekojenitede kanser saptanan olguların çoğunda RDUS bakıda belirgin kanlanma (derece 2) saptanmıştır. Hipoekojenik kanser saptanan 32 hastanın 24'ünde (\%75) 2 . derece kanlanma saptanırken, 5 'inde (\%16) 1 . derece kanlanma izlenmiştir. Üç olguda (\%9) ise RDUS'de kanlanma saptanmamıştır. Mikst ekojenitede lezyon saptanan 25 olgunun büyük çoğunluğunda (\%88) belirgin kanlanma dikkati çekmektedir. Sadece 3 olguda (\%12) minimal kanlanma saptanırken, kanlanma göstermeyen mikst ekojenitede lezyon görülmemiştir. Gri skala US bakıda kanser izlenmeyen olgularda (izoekojenik) RDUS bakıda da lezyon saptanmamıştır. Olguların tümü dikkate alındığında 3 olguda (\%5) RDUS bakıda kanlanma gözlenmemiş ve tek başına gri skala US ile lezyon saptanmıştır. Lezyonların kanlanma dereceleri ile eko özellikleri arasındaki ilişki Tablo 6'da incelenmiştir. Tabloda 2 farklı odak saptanan 2 olgudaki lezyonlar tek tek ele alınmıştır. Bu nedenle toplam odak sayısı 65 olarak belirlenmiştir.
Sadece gri skala US ile bakıda 57 (\%88) kanser saptanırken, tek başına RDUS ile bakıda 54 (\%83) tümör izlenmiştir. Buna göre tek başına gri skala US ile değerlendirmede, RDUS'ye göre daha fazla kanser odağının belirlendiği dikkati çekmektedir.

Tümörlerin Gleason skorları ile kanlanma dereceleri arasında da önemli bağlantılar tespit edilmiştir. Kanlanma özellikleri farklı iki kanser odağı taşıyan ve Gleason skorlaması yapılamayan bir hasta değerlendirmeye dahil edilmemiştir. Buna göre toplam 63 kanser odağı incelenmiş ve Tablo 7'de bulgular özetlenmiştir. RDUS ile kanlanma saptanmayan lezyonların tamamı iyi ya da orta derece diferansiye kanser grubundadır. Buna karşın belirgin kanlanma saptanan kanserlerin büyük çoğunluğu (\%98) orta ya da kötü diferansiye grupta yer almaktadır. 2. derece kanlanma saptanan sadece 1 hastada (\%2) Gleason skorunun 4 olduğu görülmüştür. Kötü diferansiye olup kanlanma göstermeyen kansere rastlanmamıştır. Minimal kanlanma (1. derece) daha çok orta derece diferansiye kanserlerde gözlenmiştir (\%50).

Tablo 6. Kanserlerin kanlanma derecelerine ve eko özelliklerine göre dağılımı.

\begin{tabular}{lcccc}
\hline Kanlanma & \multicolumn{3}{c}{ Eko Özellikleri } \\
\cline { 2 - 4 } derecesi & Hipoekojenik & İzoekojenik & Mikst ekojenik & Toplam \\
\hline Derece 0 & $3(\% 9)$ & $8(\% 100)$ & $0(\% 0)$ & 11 \\
Derece 1 & $5(\% 16)$ & $0(\% 0)$ & $3(\% 12)$ & 8 \\
Derece 2 & $24(\% 75)$ & $0(\% 0)$ & $22(\% 88)$ & 46 \\
Toplam & $32(\% 100)$ & $8(\% 100)$ & $25(\% 100)$ & 65 \\
\hline
\end{tabular}


Tablo 7. Kanserlerin kanlanma derecelerine ve Gleason skorlarına göre dağılımı.

\begin{tabular}{lcccc}
\hline Kanlanma & \multicolumn{4}{c}{ Gleason skoru } \\
\cline { 2 - 5 } derecesi & $2-4$ & $5-7$ & $8-10$ & Toplam \\
\hline Derece 0 & $5(\% 63)$ & $5(\% 15)$ & $0(\% 0)$ & 10 \\
Derece 1 & $2(\% 25)$ & $4(\% 12)$ & $2(\% 10)$ & 8 \\
Derece 2 & $1(\% 12)$ & $25(\% 73)$ & $19(\% 90)$ & 45 \\
Toplam & $8(\% 100)$ & $34(\% 100)$ & $21(\% 100)$ & 63 \\
\hline
\end{tabular}

\section{Tartışma}

Çalışmamızda prostat kanseri saptanmasında RDUS'nin gri skala US'ye ilave katkısının bulunmadığı gözlenmiştir. Ancak gri skala US ile kuşkulu lezyonların manifest hale gelmesine katkıda bulunduğu saptanmıştır. Yanısıra RDUS ile belirgin kanlanma gösteren kanserlerin, kanlanmayan ya da minimal kanlanma izlenen kanserlere göre daha yüksek maligniteye sahip oldukları gözlenmiştir.

Epstein radikal retropubik prostatektomi yapılan 185 erkek hasta üzerinde yaptığı çalışmada, Gleason skorlarının progresyonu tahmin etmede en iyi kriter olduğunu saptamıştır. Yanı sıra Gleason skorları arttıkça serum PSA değerlerinin de arttığını belirtmektedirler [10]. Bizim çalışmamızda da Gleason skorları arttıkça ortalama PSA değerlerinin de arttığı görülmüştür (Tablo 1).

Prostat kanserlerinin ekojenik yapıları hakkında değişik çalışmalarda farklı sonuçlar bildirilmektedir [11-14]. Shinohara ve ark. [13] 70 hastalık serilerinin retrospektif değerlendirmesinde, prostat kanserlerinin \%60'ının hipoekojenik, \%39'unun izoekojenik ve \%1'inin de hiperekojenik olduğunu saptamışlardır. Rifkin ve ark. [12] ise 51 hastayı kapsayan serilerinde, saptadıkları kanserlerin $\% 59$ 'unun hipoekojenik, \%12'sinin izoekojenik, $\% 20$ 'sinin mikst ekojenik ve \%10'unun ise hiperekojenik olduğunu bildirmişlerdir. Bizim çalışmamızda ise, hipoekojenik kanserler $\% 49$, izoekojenik kanserler \%12 ve mikst ekojenik kanserler \%39 oranında bulunmuştur. Diğer taraftan olgularımızın hiçbirinde hiperekojenik özellikte kanser odağı saptanmamıştır.

Çalışma grubumuzda yer alan izoekojenik kanser odakları (\%12), 8 kadran randomize biyopsi tekniği sayesinde belirlenebilmiştir. Slonim ve arkadaşları geniş serili yeni bir çalışmalarında 202 kanser odağının 57'sini (\%28) segmental randomize biyopsi ile saptadıklarını bildirmektedirler. Çalışmalarında gri skala US ile saptanan lezyonlardan biyopsi alındıktan sonra tüm kadranlardan ilave olarak segmental randomize biyopsiler alınmasını önermektedirler. Ancak, randomize biyopsilerin ilave edilmesiyle morbiditede minimal artışın da ortaya çıktığını bildirmektedirler [15].

Prostat kanserlerinin ekojenik görünümleri hakkında literatürde bildirilen değişik sonuçlar, araştırmacıların tümör ekojenitesini belirlerken farklı kriterler kullanmalarından kaynaklanmaktadır. Örneğin Rifkin'e göre, mikst ekojenitede lezyon hipo ve hiperekojenik foküslerin birlikte bulunmasını ifade etmektedir. Lezyon içinde hipoekojenik ve hiperekojenik alanlardan biri diğerinden daha fazla olabilirya da eşit bir şekilde dağılım gösterebilirler. Diğer bazı araştırmacılar ise, lezyon içinde hipoekojenik bir alan varsa, hiperekojenik odaklar dikkate alınmadan bu lezyonun hipoekojenik olduğunu kabul etmektedirler. Araştırmacılar arasında prostat kanserlerinin ekojenik özelliklerinin farklı yorumlanması yayınlanan sonuçların birbirleri ile kıyaslanmasını güçleştirmektedir [12-17].

Rifkin ve ark. [12] histolojik olarak konfirme edilmiş 51 hastayı kapsayan çalışmalarında, stromal fibrozis varlığı ve miktarı ile doğru orantılı olarak tümörün ekojenitesinin ve Gleason skorunun artığını göstermişlerdir. Sonuçlarına göre, mikst ekojenitedeki tümörler hipoekojenik olanlara göre daha yüksek dereceli grupta yer almaktadırlar.

İzoekojeniktümörlerin malignite potansiyelleri yönünden ise farklı sonuçlar bildirilmektedir. Shinohara ve ark. [13] izoekojenik tümörlerin daha çok iyi ve orta derece diferansiye grupta yer aldığını ve hipoekojenik tümörlere göre belirgin olarak benign karakterler taşıdıklarını belirtmektedirler. Rifkin ve ark. [12] bulguları da benzer şekildedir. Buna karşın Melchior ve ark. [4] izoekojenik tümörler ile hipoekojenik tümörlerin aynı derecede malign potansiyele 
sahip olduklarını ve izoekojenik tümörlerin iyi diferansiye grupta yer almadıklarını ileri sürmektedirler. Ancak aynı araştımacılar, ortalama PSA değerleri arasında anlamlı farklılık olduğunu ve izoekojenik tümörlerde PSA düzeylerinin daha düşük seviyelerde ölçüldüğünü vurgulamaktadırlar.

Bizim bulgularımız ise, Rifkin ve arkadaşlarının sonuçları ile benzerlik göstermektedir. Mikst ekojenitedeki tümör olgularımızın büyük çoğunluğu orta ve kötü diferansiye grupta yer almakta ve ortalama Gleason skorları hipo ve izoekojenik tümörlere göre daha yüksek seviyelerde bulunmaktadır. Hipoekojenik tümörlerin büyük çoğunluğu da orta derece diferansiye grupta yer almaktadır. Çalışma grubumuzda yer alan izoekojenik tümörler ise, iyi ya da orta derece diferansiye kanserler grubunda yer almaktadır. Kötü diferansiye grupta izoekojenik tümör bulunmamaktadır. Hastalarımızdaki ortalama PSA değerleri de hipo ve mikst ekojenitedeki tümörlere göre belirgin derecede düşük bulunmuştur. En yüksek ortalama PSA düzeyleri ise, mikst ekojenitedeki tümörlerde ölçülmüştür.

Literatürdeki birçok çalışmada, prostat kanserlerinin seminal veziküllere invazyonlarının kötü prognoza neden olduğu bildirilmektedir [10, 18]. Epstein ve ark. [10] seminal vezikül invazyonu saptanan 45 hastada, ortalama Gleason skorunu 7,3 olarak bulmuşlardır. Radikal prostatektomi sonuçlarına göre seminal vezikül invazyonu belirlenen yedi olgumuzda Gleason skoru ortalaması 7,3 belirlenmiştir. $\mathrm{Bu}$ olguların PSA ortalamaları yüksek olarak bulunmuştur (82 ng/ml). Bu olguların altısı sonografik olarak mikst ekojenitede izlenmiştir. Hasta sayımızın yetersizliğine rağmen, seminal vezikül invazyonu gösteren tümörlerin malignite potansiyellerinin daha yüksek olduğunu söylemek mümkündür.

Gri skala US bulguları prostat patolojilerinin histolojik tanısı için spesifik özellikler taşımamaktadır. Sonografik bulgulara bakarak karsinom, akut ve kronik prostatit, benign prostat hiperplazisi ve diğer benign patolojiler arasında ayırım yapmak çoğu kez mümkün olmamaktadır. Histopatolojik tanı kesinlikle biyopsi uygulamalarına bağlıdır. Değişik çalışmalarda tek başına gri skala US ile \%30'a varan oranlarda tümörlerin gözden kaçabileceği ifade edilmektedir [4, 11-16, 19, 20].
Prostat kanseri tanısında RDUS'nin gri skala US'ye katkısını araştırmak amacıyla yapılan çalışmalarda değişik sonuçlar elde edilmiştir. Rifkin ve ark. [5] çalışmasında, 132 kanser odağının 9'unda (\%7) gri skala US'de lezyon bulunamazken (izoekojenik tümör), RDUS ile anormal kanlanma saptanmıştır. $\mathrm{Bu}$ araştırmacılar gri skala US bulgularının yetersiz olduğunu, kuşkulu veya izoekojenik lezyonların saptanmasında RDUS'nin ilave katkı sağlayabileceğini savunmaktadırlar.

Kelly ve ark. [6] prostat kanseri tanısında RDUS'nin rolünü araştırdıkları çalışmalarında, 158 hastadan gri skala US ve RDUS sonrası biyopsiler almışlardır. Biyopsiler gri skala US ve RDUS'de saptanan lezyonlara yönelik ve değişik sayılarda sistematik olmak üzere elde olunmuştur. Serilerinde sadece bir olguda gri skala US normal iken RDUS ile tümör saptanmıştır. Tek başına gri skala US'nin duyarlılığının (olguların \%96'sı), RDUS'den (olguların \%87'si) daha yüksek olduğunu ve RDUS'nin ilavesi ile pozitif olasılık değerinin arttığını bulmuşlardır. Tartışmalarında RDUS'nin gri skala US'nin pozitif olasılık değerini arttırdığını ancak, kanser tanısında tek başına gri skala US'ye çok az katkıda bulunduğunu belirtmekteler ve RDUS'nin uygulayıcıyı dikkatli ve detaylı gri skala bakıdan uzaklaştırabileceğini savunmaktadırlar [6].

Newman ve ark. [7] ise, 43 hastaya gri skala US ve RDUS sonrası biyopsi uygulamışlardır. Gri skala US bulgularına bakılmaksızın tüm biyopsi alanlarına RDUS yapılmış ve tüm hastalardan yine gri skala US bulgularına bakılmaksızın sistematik biyopsiler alınmıştır. Tüm biyopsilerin histolojik sonuçları ve RDUS bulguları karşılaştırılmıştır. Çalışmalarında gri skala US'si normal olan yedi hastada RDUS yardımı ile tümör saptamışlardır. Sonuçlarına dayanarak RDUS'nin konvansiyonel gri skala US'ye önemli katkı sağladığını ve sistematik biyopsi alınırken gri skala US ile lezyon saptanmayan alanlardan RDUS rehberliğine baş vurulmasının faydalı olacağını ileri sürmektedirler. Yanı sıra, tüm hastalara gri skala US ve RDUS bulgularına bakılmaksızın sistematik biyopsi yapılması gerekliliğini vurgulamaktadırlar [7].

Çalışma grubumuzda gri skala US incelemesi normal olan hiçbir olguda tek başına RDUS ile tümör saptanmamıştır. Başka bir ifadeyle RDUS'nin prostat kanserlerini saptamada gri 
skala US'ye herhangi bir katkısı görülmemiştir. Hatta üç olguda (\%5) RDUS ile kanlanma izlenmemiş ve kanser odağı sadece gri skala US ile belirlenmiştir. Olguların tümü göz önüne alındığında gri skala US bakı ile saptanan 57 kanser odağının (\%88), 54 tanesinde (\%83) RDUS ile kanlanma tespit edilmiştir. Ancak gri skala US'de tespit edilen kuşkulu lezyonların daha belirgin hale getirilmesinde RDUS önemli katkılarda bulunmuştur.

Rifkin ve ark. [16] prostat kanserini diğer benign patolojilerden ayırmak amacıyla olgularında spektral Doppler inceleme yapmış ve ortalama Rİ ve Pİ değerlerini elde etmişlerdir. Sonuçlarına göre kanser ile benign patolojiler arasında anlamlı fark bulunmamış ve ayırıcı tanıda spektral incelemenin yerinin olmadığını belirtmişlerdir. Ancak kanserler arasında Gleason skorlarına göre spektral Doppler incelemesi yapmamışlardır. Bizim çalışmamızda minimal kanlanma (1. derece) gösteren kanserlerle belirgin kanlanma ( 2 . derece) gösteren kanserler arasında Rí değerleri yönünden anlamlı fark bulunmazken; PI değerlerinin 2. derece kanlanma gösteren kanserlerde önemli oranda daha yüksek bulunduğu gözlenmiştir. Buna göre Pİ değerinin yüksekliği kanserin malignite potansiyelinin yüksek olduğunu düşündürmelidir.

Alexander, AA [21] prostat kanserlerinin RDUS'de kanlanma dereceleri ile Gleason skorları arasında doğru orantılı sonuçların elde edilmesi durumunda, tümörlerin malignite potansiyelleri üzerine yeni bir sınıflamanın yapılabileceğini öne sürmektedir . Ancak Kelly ve ark. [6] serilerinde, RDUS incelemesi negatif olan 10 hastanın 6'sında yaygın prostat kanseri bulunduğunu ve bu tümörlerden ikisinin bir yıl içinde belirgin kanlanma gösterdiğini ifade etmektedirler. Bu sonuçlara göre, RDUS'de kanlanma saptanmayan tümörlerin düşük malignite derecesine sahip olduğu hipotezini reddetmektedirler [6].

Çalışma grubumuzda yer alan olgularda, kanserlerin Gleason skorları ile kanlanma dereceleri arasında önemli bağlantılar tespit edilmiştir. RDUS'de kanlanma derecesi arttıkça ortalama Gleason skorunun ve ortalama PSA değerinin arttığı saptanmıştır. Kötü diferansiye kanser saptanan 21 hastanın hepsinde RDUS'de kanlanma izlenmiştir. Bu hastaların 19'unda (\%90) belirgin kanlanma (2. derece) gözlenmiştir. Orta diferansiye kanserlerin de çoğunluğunda (\%73) belirgin kanlanmanın (2. derece) varlığı dikkati çekmektedir. İyi diferansiye tümörlerin ise çoğunda (\%63) hiç kanlanma saptanmamış veya minimal (1. derece) (\%25) kanlanma izlenmiştir. Bu sonuçlara göre, prostat kanserlerinde neovaskülarite ile malignite potansiyeli arasında doğru orantının bulunduğunu söylemek mümkün olmaktadır.

Çalışmamızdaki kısıtıılıkların başında çalışmanın küçük popülasyonda yapılmış olması ve sadece malignite saptanan olguların çalışmaya dahil edilmiş olması gelmektedir. Son yıllarda manyetik rezonans görüntüleme (MRG) tekniğindeki gelişmeler ve ileri görüntüleme yöntemleri ile prostat kanserinin lokalizasyonu ve evrelemesi daha doğru ve güvenilir bir şekilde yapılabilmektedir $[22,23]$. Multiparametrik MRG gibi yeni alternatif metodlar daha az kullanıcı bağımlı olup daha yüksek kantitatif sonuçlar verebilirdi. Ancak multiparametrik MRG'nin maliyetinin yüksek olması, kolay ulaşılabilir olmayışı ve her hastaya uygulanamaması gibi nedenlerle TRUS halen tümör lokalizasyonunu tayin etmede ve biyopsi kılavuzluğunda standart yöntem olmaya devam etmektedir.

Sonuç olarak prostat kanseri saptanmasında RDUS'nin gri skala US'ye ilave katkısı bulunmamıştır. Ancak gri skala US ile kuşkulu lezyonların manifest hale gelmesine katkıda bulunduğu gözlenmiştir. Kanserlerin kanlanma dereceleri ile Gleason skorları arasında önemli bağlantılar dikkati çekmiştir. Buna göre RDUS ile belirgin kanlanma gösteren kanserlerin, kanlanmayan ya da minimal kanlanma izlenen kanserlere göre daha yüksek maligniteye sahip oldukları gözlenmiştir.

Çıkar İlişkisi: Yazarlar çıkar ilişkileri bulunmadığını beyan eder.

\section{Kaynaklar}

1. Kirby RS, Christmas TJ, Brawer MK. Prostate cancer. London: Mosby 1996;23-33.

2. Stamey TA, McNeal JE. Adenocarcinoma of the prostate. Campbell's Urology, 6'th ed. Philadelphia: Saunders 1992:1159-1221.

3. Cooner WH, Mosley BR, Rutherford CL, et al. Prostate cancer detection in a clinical urological practice by ultrasonography, digital rectal examination and prostate specific antigen. J Urol 1990;143:1146-1154. 
4. Melchior SW, Brawer MK. Role of transrectal ultrasound and prostate biopsy. J Clin Ultrasound 1996;24:463471.

5. Rifkin MD, Sudakoff GS, Alexander AA. Prostate: techniques, results, and potential applications of color Doppler US scanning. Radiology 1993;186:509-513.

6. Kelly IMG, Lees WR, Rickards D. Prostate cancer and the role of color Doppler US. Radiology 1993;189:153156.

7. Newman JS, Bree RL, Rubin JM. Prostate cancer: diagnosis with color Doppler sonography with histologic correlation of each biopsy site. Radiology 1995;195:86-90.

8. Patel U, Rickards D. The diagnostic value of colour Doppler flow in the peripheral zone of the prostate, with histologic correlation. Br J Urol 1994;74:590-595.

9. Aarnink RG, Huynen AL, Giesen RJB, et al. Automated prostate volume determination with ultrasonographic imaging. J Urol 1995;153:1549-1554.

10. Epstein Jl, Carmichael M, Walsh PC. Adenocarcinoma of the prostate invading the seminal vesicle: definition and relation of tumor volume, grade and margins of resection to prognosis. J Urol 1993;149:1040-1045.

11. Dahnert WF, Hamper UM, Eggleston JC, Walsh PC, Sanders RC. Prostatic evaluation by transrectal sonography with histopathologic correlation: the echopenic appearance of early carcinoma. Radiology 1986;158:97-102.

12. Rifkin MD, McGlynn ET, Choi H. Echogenicity of prostate cancer correlated with histologic grade and stromal fibrosis: endorectal US studies. Radiology 1989;170:549-552.

13. Shinohara K, Wheeler TM, Scardino PT. The appearance of prostate cancer in transrectal ultrasonography: correlation of imaging and pathological examinations. J Urol 1989;142:76-82.

14. Waterhouse RL, Resnick MI. The use of transrectal prostatic ultrasonography in the evaluation of patients with prostatic carcinoma. J Urol 1989;141:233-239.

15. Slonim SM, Cuttino JT, Johnson CJ, et al. Diagnosis of prostatic carcinoma: value of random transrectal sonographically guided biopsies. AJR 1993;161:10031006.

16. Rifkin MD, Friedland GW, Shortliffe L. Prostatic evaluation by transrectal endosonography: detection of carcinoma. Radiology 1986;158:85-90.

17. Salo JO, Rannikko S, Makinen J, Lehtonen T. Echogenic structure of prostatic cancer imaged on radical prostatectomy specimens. Prostate 1987;10:1-9.

18. Paulson DF, Moul JW, Walther PJ. Radical prostatectomy for clinical stage T1-2NOM0 prostatic adenocarcinoma: long-term results. J Urol 1990;144:1180-1184.

19. Lee F, Gray JM, McLeary RD, et al. Prostatic evaluation by transrectal sonography: criteria for diagnosis of early carcinoma. Radiology 1986;158:91-95.
20. Gittes RE. Carcinoma of the prostate. N Engl J Med 1991;324:236-245.

21. Alexander AA. To color Doppler image the prostate or not: that is the question. Radiology 1995;195:11-13.

22. Fütterer $J J$, Briganti $A$, De Visschere $P$, et al. Can clinically significant prostate cancer be detected with multiparametric magnetic resonance imaging? A systematic review of the literature. Eur Urol 2015;68:1045-1053.

23. Pokorny MR, de Rooij M, Duncan E, et al. Prospective study of diagnostic accuracy comparing prostate cancer detection by transrectal ultrasound-guided biopsy versus magnetic resonance (MR) imaging with subsequent MR-guided biopsy in men without previous prostate biopsies. Eur Urol 2014;66:22-29. 